THE LANGUAGE OF LITERATURE

General Editor: N. F. Blake

Professor of English Language and Linguistics

University of Sheffield 
THE LANGUAGE OF LITERATURE

General Editor: N. F. Blake

Professor of English Language and Linguistics

University of Sheffield

Published titles

An Introduction to the Language of Literature N. F. Blake

The Language of Shakespeare

N. F. Blake

The Language of Chaucer

David Burnley

The Language of Wordsworth and Coleridge

Frances Austin

The Language of Irish Literature

The Language of D. H. Lawrence

Loreto Todd

The Language of Thomas Hardy

Allan Ingram

The Language of James Joyce

Raymond Chapman

The Language of Drama

Katie Wales

The Language of Jane Austen

David Birch

The Language of George Orwell

Myra Stokes

Roger Fowler

\section{Series Standing Order}

If you would like to receive future titles in this series as they are published, you can make use of our standing order facility. To place a standing order please contact your bookseller or, in case of difficulty, write to us at the address below with your name and address and the name of the series. Please state with which title you wish to begin your standing order. (If you live outside the United Kingdom we may not have the rights for your area, in which case we will forward your order to the published concerned.)

Customer Services Department, Macmillan Distribution Ltd, Houndmills, Basingstoke, Hampshire, RG21 2XS, England. 


\title{
The Language of George Orwell
}

\author{
ROGER FOWLER
}

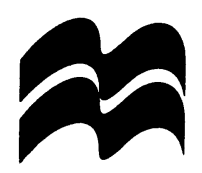




\section{(C) Roger Fowler 1995}

All rights reserved. No reproduction, copy or transmission of this publication may be made without written permission.

No paragraph of this publication may be reproduced, copied or transmitted save with written permission or in accordance with the provisions of the Copyright, Designs and Patents Act 1988, or under the terms of any licence permitting limited copying issued by the Copyright Licensing Agency, 90 Tottenham Court Road, London W1P 9HE.

Any person who does any unauthorised act in relation to this publication may be liable to criminal prosecution and civil claims for damages.

First published 1995 by

MACMILLAN PRESS LTD

Houndmills, Basingstoke, Hampshire RG21 2XS

and London

Companies and representatives

throughout the world

ISBN 978-0-333-54908-7 ISBN 978-1-349-24210-8 (eBook)

DOI 10.1007/978-1-349-24210-8

A catalogue record for this book is available from the British Library.

$\begin{array}{llllllllll}10 & 9 & 8 & 7 & 6 & 5 & 4 & 3 & 2 & 1\end{array}$

$\begin{array}{llllllllll}04 & 03 & 02 & 01 & 00 & 99 & 98 & 97 & 96 & 95\end{array}$ 


\section{Contents}

Preface vii

Acknowledgements and Editions Used ix

1 Orwell's Life and Career 1

2 Preliminaries 7

The Styles of George Orwell $\quad 7$

Linguistic Criticism 11

3 Orwell's Views on Language 19

Language and Class 20

'That horrible plummy voice from the radio' 22

Demotic Speech 24

Spoken and Written Language, and Standard English 25

'A catalogue of swindles and perversions' 28

Language and Thought 31

'An instrument which we shape for our own purposes' 33

4 A Personal Voice $\quad 35$

Linguistic Varieties $\quad 37$

Examples of the Personal Style 41

Linguistic Markers of Orwell's Idiolect 53

Orwell Over the Top $\quad 55$

5 Versions of Realism

The Three 'Realisms': Brief Characterisation 63

Descriptive Realism and the Sense of 'place' 65

Naturalism and Surrealism in Down and Out
in Paris and London

Naturalism in Homage to Catalonia 79

Realism, Judgement and Symbolism in The Road to Wigan Pier $\quad 81$ 
6 Voices of the Other $\quad 87$

$\begin{array}{ll}\text { Heteroglossia } & 88\end{array}$

Literary Representation of Speech $\quad 90$

English Dialects and Accents in the Early Fiction 93

$\begin{array}{ll}\text { Experiment in Polyphony: the Trafalgar Square } & \\ \text { Chapter in A Clergyman's Daughter } & 109\end{array}$

7 Further Aspects of Style 119

The Picturesque $\quad 119$

Heteroglossia in Burmese Days 129

8 Point of View in Orwell's Fiction 136

The Mind-style of Gordon Comstock 140

Self-narration: Coming Up for Air $\quad 148$

9 Animal Farm 159

Narrative Style in Animal Farm 164

Focalisation, Empathy and Distance 170

The Rhetoric of Dominance and the Perversion $\begin{array}{ll}\text { of Language } & 174\end{array}$

10 Nineteen Eighty-Four 181

Focalisation: The Hyperconscious Anti-hero 184

Memory, Dream and Hallucination $\quad 191$

The Golden Country $\quad 193$

Sordid Realism $\quad 195$

$\begin{array}{ll}\text { Violence } & 199\end{array}$

Heteroglossia and the Grotesque 203

Newspeak and the Language of the Party 211

$\begin{array}{ll}\text { Notes } & 228\end{array}$

$\begin{array}{ll}\text { Bibliography } & 241\end{array}$

$\begin{array}{ll}\text { Index } & 246\end{array}$ 


\section{Preface}

When I was invited to write a study of the language of a writer of particular interest to me, I thought a lot about the choice of a possible subject, and George Orwell suddenly 'clicked'. He is a writer and a political thinker whom I have admired since my student days; he is a tremendously versatile stylist; he not only practises the arts of language, but the central theme in much of his work is language itself; and his interest in language centres on topics which have been my own preoccupations in linguistics: language as a political instrument, as an expression of or an inhibitor of thought, and as a practice which is central to all the workings of society: the media, the formation of history, literature, the ideas and the play of people.

Orwell's political and social analyses have had a profound influence on the way we think, largely thanks to the power and the memorable phrasing of his last two books, Animal Farm and Nineteen Eighty-Four. But the language in which he expressed his vision has been largely neglected. While James Joyce and Virginia Woolf, for example, are recognised as having created distinctive and influential linguistic structures for the representation of consciousness, and D. H. Lawrence is seen as having forged a powerful modern romantic style, Orwell is not seen as a stylist, but as a source of political ideas, strikingly worded. In this book I have tried to show, through detailed analysis of his language, how he evolved the distinctive 'Orwellian voice' (which some critics have mentioned, but not analysed). Beyond the personal voice, there is in fact a great diversity of stylistic technique: precise description, striking figurative expression, pastoral, naturalism, surrealism, representation of thought, powerful evocations of violence, a keen eye for the grotesque and an ear for what I have called 'voices of the other', trenchant parody of political styles; finally, quite different from these heightened modes of writing, the purest simplicity of style in the satires of Animal Farm and the Newspeak Appendix to Nineteen Eighty-Four.

Although I have not consciously attempted to write a history of Orwell's stylistic development, this book follows roughly the sequence of his writing career. I was determined to take his early 


\section{viii PREFACE}

fiction and non-fictional writings seriously, not least because the early books, particularly the novels, tend to get short shrift. Most of the techniques of style of his last writings are deployed in lively and effective ways early in his career. It could be argued - though I have not pressed this argument - that there is a fundamental unity to his lifetime's writings, despite their apparent diversity.

This study uses, broadly speaking, the theory and the analytic concepts of the method of 'linguistic criticism' as it has been developed over the past fifteen years or so. That is to say, I not only describe the patterns of language which form Orwell's various styles of writing, but also discuss their functions within the composition of the books and in relation to aspects of the historical context (space permits far less of this than I would have liked). Not only linguistic concepts are used, but also ideas drawn from French and Russian studies of literature and language: particularly in the areas of 'point of view' (focalisation) and 'voices of the other'. I have found the notion of 'heteroglossia', and a cluster of related ideas, originating in the work of Mikhail Bakhtin, particularly relevant to Orwell. Being conscious that 'jargon' can be off-putting to the student of literature, I have kept technical terminology to a minimum, and explained such terms as we do need as we go along.

ROGER FOWLER 


\section{Acknowledgements and Editions Used}

The author and publishers wish to thank the following for permission to use copyright material:

A. M. Heath \& Company Ltd on behalf of the Estate of the late Sonia Brownell Orwell and Martin Secker \& Warburg, and Harcourt Brace \& Company, for excerpts from George Orwell, 'Shooting an Elephant' from Shooting an Elephant and Other Essays, Copyright (C) 1950 by Sonia Brownell Orwell and renewed 1978 by Sonia PittRivers; George Orwell, 'Politics and the English Language' from Shooting an Elephant and Other Essays, Copyright (c) 1946 by Sonia Brownell Orwell and renewed 1974 by Sonia Orwell; George Orwell, Burmese Days, Copyright (C) 1934 by George Orwell and renewed 1962 by Sonia Pitt-Rivers; George Orwell, Coming Up For Air and George Orwell, Down and Out in Paris and London, Copyright (C) 1933 by George Orwell and renewed 1961 by Sonia Pitt-Rivers; George Orwell, A Clergyman's Daughter and George Orwell, Animal Farm, Copyright (C) 1946 by Harcourt Brace \& Company and renewed 1974 by Sonia Orwell; George Orwell, Nineteen Eighty-Four, Copyright (C) 1949 by Harcourt Brace \& Company and renewed 1977 by Sonia Brownell Orwell; George Orwell, 'Why I Write', from Such, Such Were the Joys, Copyright (C) 1953 by Sonia Brownell Orwell and renewed 1981 by Mrs George K. Perutz, Mrs Miriam Gross and Dr Michael Dickson, executors of the estate of Sonia Brownell Orwell; George Orwell, Homage to Catalonia, Copyright (C) 1952 and renewed 1980 by Sonia Brownell Orwell; George Orwell, Keep the Aspidistra Flying, George Orwell, The Road to Wigan Pier, George Orwell, The Collected Essays, Journalism and Letters of George Orwell, Volume I: An Age Like This 1920-1940, Volume II: My Country Right or Left 1940-1943, Volume III: As I Please 19431945, Volume IV: In Front of Your Nose 1945-1950, edited by Sonia Orwell and Ian Angus, Copyright (c) 1968 by Sonia Brownell Orwell. 
Every effort has been made to trace all the copyright-holders, but if any have been inadvertently overlooked the publishers will be pleased to make the necessary arrangement at the first opportunity.

For quotations and references to Orwell's works, I have tried to use accessible editions, as follows:

Animal Farm, Penguin, 1973; Burmese Days, Penguin, 1967; A Clergyman's Daughter, Penguin, 1964; The Collected Essays, Journalism and Letters, ed. Sonia Orwell and Ian Angus, 4 volumes, Penguin, 1968; Coming Up for Air, Penguin, undated reprint of 1962 edition; Down and Out in Paris and London, Secker and Warburg, 1986; Homage to Catalonia, Penguin, 1984; Keep the Aspidistra Flying, Penguin, 1975; Nineteen Eighty-Four, Penguin, 1984; The Road to Wigan Pier, Penguin, 1984. 